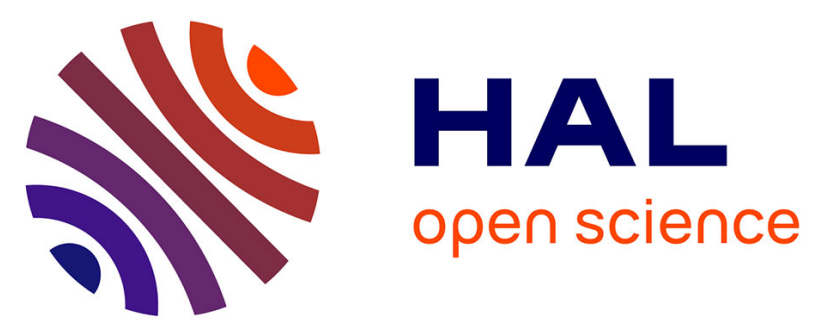

\title{
Mutant swarms of a totivirus-like entities are present in the red macroalga Chondrus crispus and have been partially transferred to the nuclear genome
}

Sylvie Rousvoal, Betty Bouyer, Camilo López-Cristoffanini, Catherine Boyen, Jonas Collén

\section{To cite this version:}

Sylvie Rousvoal, Betty Bouyer, Camilo López-Cristoffanini, Catherine Boyen, Jonas Collén. Mutant swarms of a totivirus-like entities are present in the red macroalga Chondrus crispus and have been partially transferred to the nuclear genome. Journal of Phycology, 2016, 52 (4), pp.493-504. 10.1111/jpy.12427 . hal-01320013

\section{HAL Id: hal-01320013 https://hal.sorbonne-universite.fr/hal-01320013}

Submitted on 23 May 2016

HAL is a multi-disciplinary open access archive for the deposit and dissemination of scientific research documents, whether they are published or not. The documents may come from teaching and research institutions in France or abroad, or from public or private research centers.
L'archive ouverte pluridisciplinaire HAL, est destinée au dépôt et à la diffusion de documents scientifiques de niveau recherche, publiés ou non, émanant des établissements d'enseignement et de recherche français ou étrangers, des laboratoires publics ou privés. 
5 Sylvie Rousvoal ${ }^{1,2}$, Betty Bouyer ${ }^{1,2}$, Camilo López-Cristoffanini ${ }^{1,2,3}$, Catherine 6 Boyen $^{1,2} \&$ Jonas Collén ${ }^{1,2}$

MUTANT SWARMS OF A TOTIVIRUS-LIKE ENTITY ARE PRESENT IN THE

RED MACROALGA CHONDRUS CRISPUS AND HAVE BEEN PARTIALLY

TRANSFERRED TO THE NUCLEAR GENOME

${ }^{1}$ CNRS, UMR 8227, Integrative Biology of Marine Models, Station Biologique de Roscoff, CS 90074, 29688 Roscoff cedex, France

${ }^{2}$ UMR 8227, Integrative Biology of Marine Models, Station Biologique de Roscoff, Sorbonne Universités, UPMC Univ Paris 06, CS 90074, 29688 Roscoff cedex,

France

${ }^{3}$ Present address Departament de Biologia Vegetal, Universitat de Barcelona, 08028 Barcelona, Spain

\section{ABSTRACT}

Chondrus crispus Stackhouse (Gigartinales) is a red seaweed found on North Atlantic rocky shores. Electrophoresis of RNA extracts showed a prominent band with a size of around 6,000 bp. Sequencing of the band revealed several sequences with similarity to totiviruses, double-stranded RNA viruses that normally infect fungi. This virus-like entity was named $\mathrm{CcV}$. It should probably be regarded as an extreme viral quasispecies or a mutant swarm since low identity $(<65 \%)$ was found between sequences. Totiviruses typically code for two genes: one capsid gene ( $\mathrm{gag}$ ) and one RNA-dependent RNA polymerase gene ( $p o l)$ with a pseudoknot structure 
between the genes. Both the genes and the intergenic structures were found in the $\mathrm{CcV}$ sequences. A non-identical gag gene was also found in the nuclear genome of C. crispus, with associated EST and upstream regulatory features. The gene was presumably horizontally transferred from the virus to the alga. Similar dsRNA bands were seen in extracts from different life cycle stages of $C$. crispus and from all geographical locations tested. In addition, similar bands were also observed in RNA extractions from other red algae; however, the significance of this apparently widespread phenomenon is unknown. No phenotype caused by the infection nor any virus particles, or capsid proteins were identified; thus, the presence of viral particles has not been validated. These findings increase the known host range of totiviruses to include marine red algae.

Key words: Chondrus, dsRNA, mutant swarm, Rhodophyta, totivirus, virus

\section{INTRODUCTION}

Viruses play a key role in the functioning of marine ecosystems (Fuhrman 1999, Suttle 2005, 2007). Their prevalence and diversity contribute to the control of the abundance, the diversity, and the productivity of many marine organisms and influence global nutrient and energy cycles. For example, it is estimated that viruses are responsible for the mortality of $20 \%$ of the oceans' biomass every day and that their abundance is 15 times higher than that of prokaryotes, even if the biomass is less. Because of the increasing understanding of the relevance of marine viruses a substantial research effort has been made to study their ecology, physiology, and molecular biology. Marine viruses have been shown to infect a multitude of various 
organisms from cyanobacteria to whales. Viruses have also been suggested to represent the most genetically diverse biological entities in the ocean.

There are various types of viruses that differ in terms of their genetic material: single-stranded DNA (ssDNA), double-stranded DNA (dsDNA), single-stranded RNA (ssRNA), and double-stranded RNA (dsRNA). The sizes of the viral genomes vary between a couple of thousand to several million base pairs with RNA viruses normally having smaller genomes (Philippe et al. 2013). Plant viruses can be divided into four types based on their lifestyle: persistent, chronic, endogenous and acute. Infections with persistent plant viruses typically do not induce any phenotype and are transmitted via gametes. In plants, this type of lifestyle has hitherto been known exclusively from dsRNA viruses. Acute viruses can normally be transported between plants and typically produce a phenotype (Roossinck 2010).

One area where effects of viruses on marine organisms have been more intensely studied is the interaction between viruses and phytoplankton (e.g. Etten et al. 1991, Reisser 1993, Brussaard et al. 2004, Lang et al. 2009). It has been observed (Suttle 2007) that viruses have a key role in controlling the progress, and sometimes the collapse, of many phytoplankton blooms (e.g. Emiliania huxleyi, Phaeocystis globosa and Heterosigma akashiwo). Another system that has been studied in more detail is the ecological consequences of the interaction between the green unicellular alga Ostreococcus and its DNA virus (e.g. Derelle et al. 2008, 2015, Moreau et al. 2010). It has therefore been suggested that viral dynamics are one of the explanations to the paradox for the plankton (Fuhrman 1999); successful plankton species, due to their abundance, are more likely to succumb to virus-induced collapses of the populations than are rare species. This preserves the diversity of the phytoplankton. 
We have, thus, some information on the interaction between unicellular algae and viruses as well as its importance.

Seaweeds are an important component of the coastal ecosystem; however, much less is known about viruses that infect seaweeds or macroalgae than their unicellular counterparts (Schroeder 2011). One exception is a virus that was found in the brown alga Ectocarpus siliculosus. This dsDNA virus, EsV-1, belonging to the Phaeoviruses with a genome of $335,593 \mathrm{bp}$, becomes associated to the host's genome (Müller et al. 1990, Klein et al. 1993, Delaroque et al. 2001, Cock et al. 2010). The virus particles are most expressed during reproduction and spread through infection of spores and gametes. It is manifested by malformed gametangia and lysis of swollen hyaline cells (Müller et al. 1990, 2000). Similar phaeoviruses have also been found in other brown algae, including, Feldmannia irregularis, F. simplex, (Müller and Frenzer 1993, Friess-Klebl et al. 1994), Hincksia hincksiae (Kapp et al. 1997), Botrytella micromora (as Sorocarpus uvaeformis) (Oliveira and Bisalputra 1978), E. fasciculatus (Sengco et al. 1996), Streblonema sp. (La Claire II and West 1977), and Pylaiella littoralis (Maier et al. 1998). Virus infections have also been observed in the green coenocytic macroalga Bryopsis cinicola (Koga et al. 1998, 2003). Here one $4.5 \mathrm{kbp}$ sequence belonging to the dsRNA virus family Partitiviridae was found associated with mitochondria and for four others of about $2 \mathrm{kbp}$ with chloroplasts (Ishihara et al. 1992).

Virus infections in red algae are much less studied than in brown algae; however, virus-like particles have been found, by electron microscopy-studies, in the cytoplasm of the freshwater red alga Sirodotia tenuissima (Lee 1971) and in the marine species Acrochaetium (Audouinella) saviana (Pueschel 1995), Gracilaria epihippisora (Apt and Gibor 1991), and G. verrucosa (Tripodi and Beth 1976). In 
addition, gall-like structures have been found in several species of Bostrychia including B. kelanensis, B. radicosa, B. simpliciuscula, and B. tenella, and in some cases the galls have been associated with virus-like particles (West et al. 2013). For all of these possible red algal viruses the type of virus is unknown, no sequences are known, and the only reported phenotype is the formation of galls. Thus, the prevalence and importance of viruses in red algal biology is virtually unknown.

Chondrus crispus, or Irish moss, is a common, often intertidal red macroalga that has been promoted as a model species for florideophyte red algae (Collén et al. 2014). It has a triphasic life cycle with morphologically similar tetrasporophytes (diploid), male, and female gametophytes (haploid) and morphologically different carposporophytes (diploid) on the female gametophyte. The 105-Mbp genome was recently sequenced and codes for 9,606 genes (Collén et al. 2013). During the purification of RNA for the Chondrus genome project a prominent band of unusual size was seen on agarose gels; sequencing of this band showed sequence similarities to totiviruses, dsRNA viruses that normally infect fungi.

\section{MATERIALS AND METHODS}

Algal material and culture. Unless explicitly stated otherwise studies were carried out on a strain of the red alga Chondrus crispus Stackhouse (Gigartinales) grown in unialgal culture (Collén et al. 2013) at the Station Biologique de Roscoff, from a male gametophyte collected at Peggy's Cove, Nova Scotia, Canada $\left(44^{\circ} 29^{\prime \prime} \mathrm{N}, 63^{\circ} 55^{\prime} \mathrm{W}\right)$ in 1985 by Juan Correa. For the other specified C. crispus life cycle stages, samples were collected near Roscoff or in other specified locations. 
RNA extraction and purification. Chondrus crispus RNA was extracted based on a protocol adapted from Apt et al. (1995). Briefly, frozen tissue ( 1 g) was ground with a small amount of sand and liquid $\mathrm{N}_{2}$ in a mortar and pestle. The powder was transferred to a $50 \mathrm{ml}$ Teflon tube, and extracted with $15 \mathrm{ml}$ extraction buffer (100 mM Tris- $\mathrm{HCl} \mathrm{pH}$ 7.5, $1.5 \mathrm{M} \mathrm{NaCl}, 50 \mathrm{mM}$ EDTA, $50 \mathrm{mM}$ DTT, $2 \%$ CTAB) for 60 min, with continuous shaking at $200 \mathrm{rpm}$ at room temperature. Cellular debris was removed after centrifugation with one volume of chloroform-isoamylic alcohol (24:1) at $10,000 \mathrm{~g}$ and $4{ }^{\circ} \mathrm{C}$ for $20 \mathrm{~min}$. The aqueous phase was transferred to a Teflon tube and polysaccharides were precipitated with 0.25 volumes of $100 \%$ ethanol and centrifuged with one volume of chloroform-isoamylic alcohol (24:1) at $10,000 \mathrm{~g}$ and $4{ }^{\circ} \mathrm{C}$ for $20 \mathrm{~min}$. Total RNA was precipitated overnight with $3 \mathrm{M} \mathrm{LiCl}$ and $1 \%$ of $\beta$-mercaptoethanol; after centrifugation, the pellet was dissolved in TE buffer (10 mM Tris-HCl pH 7.5, 1 mM EDTA). RNA quality was assessed on $1.5 \%$ agarose gel stained with $0.1 \mu \mathrm{g} / \mathrm{ml}$ ethidium bromide (EtBr) and quantified using a NanoDrop ND-2000 spectrophotometer (NanoDrop products, Wilmington, DE, USA). $\mathrm{CsCl}$ separation of total nucleic acids was used to purify dsRNA in $2 \mathrm{ml}$ polyallomer tubes with $0.95 \mathrm{~g} / \mathrm{ml} \mathrm{CsCl}$ in $\mathrm{TE}$ and $50 \mu \mathrm{l}$ of $10 \mathrm{mg} / \mathrm{ml} \mathrm{EtBr}$ solution. The solution was centrifuged for $24 \mathrm{~h}$ at $90,000 \mathrm{rpm}$. The dsRNA band was recovered and the EtBr was extracted with TE-saturated butanol. The remaining aqueous phase containing the dsRNA was diluted three times and isopropanolprecipitated over-night at $-20^{\circ} \mathrm{C}$. After centrifugation for $45 \mathrm{~min}$ at $18,000 \mathrm{~g}$ and 4 ${ }^{\circ} \mathrm{C}$, the pellet was washed with $200 \mu \mathrm{L} 80 \%$ ethanol and recentrifuged for $30 \mathrm{~min}$ at $18,000 \mathrm{~g}$ and $4{ }^{\circ} \mathrm{C}$; the pellet was finally dissolved in $100 \mu \mathrm{L}$ of TE and kept at -20 ${ }^{\circ} \mathrm{C}$ until use. 
Cloning and sequencing. Cloning of RNAs was adapted from Djikeng et al. (2008) using random-tagged primers and RNA purified from agarose gels. Briefly, $100 \mathrm{ng}$ of RNA and 2 pmol of random tagged primers were denaturated for 5 min at $70{ }^{\circ} \mathrm{C}$. The first cDNA strand was synthetized using the Improm-RT polymerase Kit (Promega), after annealing $5 \mathrm{~min}$ at $25^{\circ} \mathrm{C}$, elongation $1 \mathrm{~h}$ at $38^{\circ} \mathrm{C}$, and inactivation 15 min at $70{ }^{\circ} \mathrm{C}$ the RNA strand was degraded with 2 units of RNase $\mathrm{H}, 20$ min at 37 ${ }^{\circ} \mathrm{C}$. The second strand was generated using 2 pmol of random tagged primer and 2.5 units of Klenow. After purification cDNAs were amplified by PCR and cloned in TOPO-TA (Invitrogen). Race PCR was performed to obtain longer sequences using $75 \mathrm{ng}$ of gel-purified viral RNA with $1.2 \mu \mathrm{M}$ specific primers, drawn from a first sequence alignment in the polymerase region, and $1.2 \mu \mathrm{M}$ universal primers., Reverse transcribtion was carried out at $42{ }^{\circ} \mathrm{C}$ for 90 min, using SmartScribe reverse transcriptase Protocol (Clontech). After a 1/12.5 dilution, $1 \mu$ l of cDNA was amplified in a total volume of $25 \mu \mathrm{l}$, with $400 \mathrm{nM}$ of each specific and universal primers, $0.2 \mathrm{mM}$ dNTP, Pfu buffer, using 1.25 units Pfu DNA polymerase (Invitrogen). After a denaturation step for 4 min at $94{ }^{\circ} \mathrm{C}$, samples were cycled in a ABI2700 thermocycler as following: $30 \mathrm{sec}$ at $94{ }^{\circ} \mathrm{C}, 30 \mathrm{sec}$ at $60{ }^{\circ} \mathrm{C}, 6 \mathrm{~min}$ at $72{ }^{\circ} \mathrm{C}$ for 5 cycles followed by 5 cycles of $30 \mathrm{sec}$ at $94{ }^{\circ} \mathrm{C}, 30 \mathrm{sec}$ at $56{ }^{\circ} \mathrm{C}, 6 \mathrm{~min}$ at $72{ }^{\circ} \mathrm{C}$ and 25 cycles of $30 \mathrm{sec}$ at $94{ }^{\circ} \mathrm{C}, 30 \mathrm{sec}$ at 52 or $56^{\circ} \mathrm{C}$, depending on the considered specific primer, $6 \mathrm{~min}$ at $72{ }^{\circ} \mathrm{C}$ and a final step of $10 \mathrm{~min}$ at $72{ }^{\circ} \mathrm{C}$. PCR products $(2$ $\mu \mathrm{L}$ ) were directly cloned with TOPO-TA cloning (Invitrogen) and transformants were screened for size by PCR and sequenced using universal primers M13Forward and M13Reverse. Tail-PCR experiments were performed using combined random and specific primers; 200 ng RNA were reverse transcribed using 200 nM GSP1 and $2 \mu \mathrm{M}$ random primer RP1, using one step Access quick RT-PCR 2-fold master Mix 
(Promega) in a $20 \mu 1$ total volume, according to the manufacturer specifications. The second step included $2.5 \mu \mathrm{l}$ of the first 50 -fold diluted amplified sample, $2 \mu \mathrm{M}$ of $\mathrm{RP} 1$ and $200 \mathrm{nM}$ internal GSP2, $3 \mathrm{mM} \mathrm{MgCl} 2,0.2 \mathrm{mM}$ dNTP, Go-Taq buffer and 1 unit Go-Taq polymerase (Promega). The third step is consisted in the same protocol as the second step, including a 50-fold dilution of the sample and $2 \mu \mathrm{M}$ of RP1 and $200 \mathrm{nM}$ of internal GSP3.

The cloning and sequencing effort generated only small sequence fragments in the capsid part and in the polymerase sequence region; in addition, race or tail-PCR never permitted amplification of the intergenic part, which can be described as a complex pseudoknot structured sequence. Because we demonstrated that at least seven different sequences could be cloned, with regard to the partial sequences motif obtained, we decided to try to extend some of the contigs obtained; using specific primers and one-step RT-PCR cross amplification between ends of the capsid part and the RdRp part to test whether extremities were from the same virus fragment or not. We started from $30 \mathrm{ng}$ of $\mathrm{CsCl}$ purified dsRNA, denaturated for 4 min at $99{ }^{\circ} \mathrm{C}$, reverse transcribed for $45 \mathrm{~min}$ at $45{ }^{\circ} \mathrm{C}$ and the PCR cycling parameters were programmed as follows: 4 min at $95^{\circ} \mathrm{C}$, and 32 cycles of $30 \mathrm{sec}$ at $95{ }^{\circ} \mathrm{C}, 30 \mathrm{sec}$ at $54{ }^{\circ} \mathrm{C}, 3 \mathrm{~min}$ at $72{ }^{\circ} \mathrm{C}$ in a $2700 \mathrm{ABI}$ thermocycler. Sequencing was performed using capillary electrophoresis on an ABI prism 3100 sequencer (Applied Biosystems, Foster City, CA, USA) with 50-cm capillaries.

DNase and RNase essays. To discriminate between DNA and RNA, we compared DNase and RNase digestion on total nucleic acid extracts. We subjected $1.5 \mu \mathrm{g}$ of total nucleic acid to 2 units of Turbo DNaseI (Ambion) or 1 unit of RNaseA (Macherey Nagel) for $1 \mathrm{~h}$ at $40^{\circ} \mathrm{C}$. After precipitation, the samples were loaded on 1 $\%$ agarose gel in TAE stained with EtBr. 


\section{RESULT AND DISCUSSION}

Native agarose gel electrophoresis of RNA extracts from Chondrus crispus showed, in addition to rRNA and mRNA (and some DNA contamination), one prominent band with a size of approximately $6,000 \mathrm{bp}$. This band was not affected by DNAse treatment but disappeared after treatment with RNAse (Figure 1A). The bands were much less visible after denaturation of the RNA extract on a denatured gel (Figure 1B) than on a native gel. This sensitivity to RNAse indicated that the bands were made of RNA and likely double-stranded since the intensity was greatly diminished on a denatured gel. This is caused by the stronger affinity of the ethidium bromide stain to double-stranded RNA than single-stranded RNA (Sambrook and Russell 2006).

The probably double-stranded RNA band was purified, reverse transcribed using random priming, and partially sequenced. Several sequences were attained which showed very high sequence diversity and could, thus, not be assembled in a continuous sequence. Several fragments were found to be similar to Xanthophyllomyces dendrorhous virus (XdV) (Figure 2) and this sequence was used to align the sequences from $C$. crispus. $\mathrm{XdV}$ is a double-stranded RNA virus, belonging to the totivirus (Baeza et al. 2012). The genome of totiviruses, typically with a genome size 4.6-6.3 kbp, normally codes for two proteins, one capsid ( $g a g$ ) gene and one RNA-dependent RNA polymerase ( $p o l)$ gene with partially overlapping open reading frames (ORFs). The sequences from the tentative $C$. crispus virus $(\mathrm{CcV})$, contained partial sequences from both genes (Figure 3 and 4).

Considerable efforts were made to try to obtain a full sequence, but each approach, 
including SISPA method, race- or tail PCR, with degenerated, specific, or random PCR primers gave sequences that corresponded to new viral sequences instead of one specific sequence. This indicated a considerable sequence diversity within the $\mathrm{CcV}$.

It should be noted that the host strain of $C$. crispus used was artificially forced through a bottleneck of reduced size to reduce the possibility of the strain being a chimera before the genome sequencing (Collén et al. 2013) and thereafter grew vegetatively. The origin of the strain represents milligrams of tissue so that no nuclear sequence diversity was detected during genome sequencing.

The high error rate of viral replication with an RNA-dependent RNA polymerase compared to a DNA polymerase generates sequence diversity within viral populations that is higher than in cellular organisms. This causes the formation of quasispecies or mutant swarms (Andino \& Domingo 2015). The $\mathrm{CcV}$ seems to be an extreme example of this with very high sequence diversity, represented by the 20$65 \%$ amino acid identity found between sequences (Table 1). Compared with other dsRNA viruses, such as the polio virus with two nucleotide mutations per genome or less than $0.03 \%$ difference in nucleotidic sequences (Vignuzzi et al. 2006) and a similarly low diversity in the St. Louis encephalitis virus (Ciota et al. 2011). The genetic diversity of $\mathrm{CcV}$ is thus several orders of magnitude higher. One explanation for this higher sequence diversity could be the absence (or rarity) of horizontal spreading of totiviruses compared to the polio and encephalitis viruses. To our knowledge, the sequence diversity of totiviruses within one host has only been reported as different viruses e.g. the $X$. dendrorhous virus XdVL1 and XdVL2 (Baeza et al. 2012) which are less divergent than the $\mathrm{CcV}$ sequences. It should be noted that despite the large sequence variability only one distinct band was seen, implying sequence diversity rather than size diversity and also that size is conserved 
even though the sequence is not. In addition, the acquired sequences typically coded for open reading frames. The $\mathrm{CcV}$ system is therefore a potentially interesting system to study the biology of quasispecies and a model to study viral evolution with previously unknown features.

\section{Compared to totiviruses from, for example, X. dendrorhous, Saccharomyces}

cerevisiae and Tuber aestivum, the major conserved amino acid residues described in the consensus sequence of the totivirus pol gene (Baeza et al. 2012) are present in the $\mathrm{CcV}$ sequence (Figure 3). This is also true for domains 5 and 6, which have been demonstrated to be essential for viral function (Ribas 1992, Routhier 1998). Together, this strongly indicates that functional dsRNA from a totivirus-like entity is present in C. crispus.

The totiviruses belong to the mycoviruses which are widespread in yeasts and filamentous fungi but have not been reported from algae. Typically, they do not possess extracellular infections modes, are not associated with obvious disease symptoms, and do not exhibit harmful effects (Ghabrial and Suzuki, 2009). Only a few reports of phenotype modifications like hypovirulence or antifungal activity have been described (Pearson et al, 2009, Magliani 1997). Moreover, natural vectors are so far unknown (Ghabrial and Suzuki, 2009). It has been suggested that the dominant mode of diversification in most totiviruses is codivergence, parallel diversification between host and parasite (Göker et al, 2011). The large sequence diversity found in $\mathrm{CcV}$ indicates that other phenomena are probably occurring in the interaction between C. crispus and $\mathrm{CcV}$.

Viruses from the totiviridae family are mainly found in fungi and protozoa. Penaeid shrimp infectious myonecrosis virus (IMNV), isolated from the Pacific white shrimp, 
was the first totivirus described infecting a host other than a fungus or a protozoan (Nibert, 2007). Another virus, DTV, genetically related to IMNV was found to infect a Drosophila cell line (Wu et al., 2010). Totiviruses have also been isolated from mosquitoes (Armigeres subalbatus) (Zhai et al., 2010, Isawa et al., 2011). The viruses isolated from mosquitoes are genetically similar to IMNV and DTV (Isawa et al., 2011). A totivirus, related to the Giardiavirus, has also been found in salmon. (Haugland et al., 2011). Together with our data presented here, this shows that the host range for totivirus is relatively large within the eukaryotes.

The totivirus genome organization is characterized by a non-segmented dsRNA, with two genes, gag and pol, encoding two overlapping proteins, a capsid protein $(\mathrm{CP})$ and an RNA-dependent RNA polymerase $(\mathrm{RdRp})$. In most totiviruses, the $(+)$ strand viral transcript is flanked by a 5' and a 3'-UTR and directs the translation of the CP protein and a smaller CP-RdRp fusion protein via a -1 ribosomal frameshift. The ribosomal -1 frameshift site consists of a heptamer with the consensus motif XXXYYYZ, (X represents any nucleotide, Y represents A or U, and Z represents A, C or U) preceded by a GC dinucleotide (Jacks et al., 1988; Bekaert et al., 2003). The heptamer is followed by a short region preceding a stable RNA secondary structure, such as a pseudoknot or hairpin. The translational efficiency has been demonstrated to be directly related to the stability of these structures (Bidou et al. 1997). Slippery sites can promote a low level of frameshifting and downstream pseudoknot structures stimulate this process (Giedroc et al. 2000). In the 166 bp overlapping part of the sequence of $\mathrm{CcV} 2$ a putative slippery site, GGGUUUU, is located 18 nucleotides upstream a pseudoknot type structure. The structure has an estimated free energy at $18.85 \mathrm{kcal} / \mathrm{mol}$ (Figure 4). Thus, the $\mathrm{CcV}$ genome is organized as described in other totiviruses with two overlapping ORF including a 5'-ORF coding a capsid protein 
and a 3'-ORF coding an RNA-dependent RNA polymerase. This involves an ORF disruption with an internal stop codon and -1 ribosomal frameshift.

Viral sequences from various families are sometimes found integrated into the host organism's genome (Holmes 2011). A search using the CcV sequence in the sequenced $C$. crispus nuclear genome showed that one non-identical copy of the gag gene was present (Fig 4B). RNAseq data showed expression of this gene in $C$. crispus (not shown). Sequence analysis suggests that the gene also contains regulatory sequences (see below). This indicates that a transfer has occurred from the virus to the $C$. crispus genome. This type of transfer between endogenous viral elements from non-retroviral RNA viruses is known from insects (Chrochu et al. 2004), other animals (Katzourakis and Gifford 2010), and plants (Chiba et al. 2011). For the viral genes found in plant genomes they represented both single- and doublestranded viruses of various families. There is evidence that totiviral and partitiviral genes are transferred frequently into the nuclear genome of eukaryotes, and that some transferred genes have functions in the recipient genomes since totivirus-like sequences have been identified in, for example, Medicago truncatula, Lotus japonica, and Populus trichocarpa, where they have been matched to the gag gene of the Vicia cryptic virus M (Liu et al. 2010). ESTs from totiviruses have also been found in a cDNA library from the diatom Phaeodactylum tricornutum (Liu et al. 2012), but it is unknown if this was due to incorporation in the genome or caused by the presence of viral entities. Normally, after integration of viral gene sequences in a genome the genes start to degenerate (Zwart et al. 2014). Considering that the gag gene in the nuclear genome is full length and has EST support, this suggests that either the gene provides an advantage to $C$. crispus or that the integration is recent. It could be noted that transgenic maize expressing the totiviral protein KP4 is more 
resistant to fungal infection (Allen et al. 2011) and thus, incorporation of viral genes may have positive effects. No ESTs or presence in the genome were found for the pol gene in C. crispus.

A close analysis of nuclear genome regions around the gag gene gave unexpected results (Figure 6). Consensus sequences of prokaryote-type promoters were found in the upstream part of the gene. This includes a sigma70 type promoter located -11 of the TATAAA-box and -38 of the TTGAGA-box preceded by a CAAT-box located 67 before a putative start codon. Using yeast mitochondrial codon table instead of the eukaryote nuclear one results in a unique reading frame for the cap gene from the methionine codon found downstream the TATA-box. Interestingly, 35 aa preceding the putative gag start codon show similarities with a bacterial protein from Simkania nevegensis. Furthermore, in the same reading frame 24 aa sequence homologous to the cytochrome P450 (CYP) CYP808A2 (XP_005710778.1) from C. crispus. Preceding the putative CYP gene are several putative regulatory boxes, three successive adjacent E-Boxes, followed by a G-Box, and a GCC-Box.

An E-Box is a cis-acting element, a conserved DNA sequence involved in regulation of gene expression linked to environmental and physiological signaling. These elements serve as binding sites for transcriptional activators, and have been demonstrated to be important for circadian gene expression (Giuliano et al., 1988, Staiger et al, 1989, Williams et al., 1992). For example, in the green alga

\section{Chlamydomonas reinhardtii, upregulation of the C3 subunit of the CHLAMY1}

RNA-binding protein is mediated by an E-box element in its promoter; causing temperature-dependent up-regulation of $\mathrm{C} 3$, its circadian expression, and its coregulation by $\mathrm{C} 1$ (Seitz et al, 2010). The G-Box is a conserved DNA sequence in plants that has been described as a putative sugar sensor involved in starch 
catabolism (Reinhold et al., 2011). A close proximity of the G-Box and the GCC-box is often found in tobacco and linked to the regulation of gene expression during plant defense responses (Buttner, 1997). GCC-box sequences in plants are promoter elements involved in the regulation of expression of plant defense genes against biotic or abiotic stressors and play an important role in relaying pathogen-initiated signals and the activation of plant defense responses (Solano et al, 1998, Brown et al, 2003; Shenk et al, 2000; Reymond et al, 1998). GCC boxes have also been characterized in tomato endochitinase, glucanase and osmotin genes (Tournier et al, 2003). This gene structure rich in sensor motifs and a viral-type sequence indicates that gene expression is modulated by changes in environmental or physiological conditions.

We used the gag and pol sequences from $\mathrm{CcV}$ and the nuclear gag sequence to understand the phylogeny of the $\mathrm{CcV}$. The sequences for the gag and pol genes were compared with other sequences of totiviruses found in GenBank in December 2015. The pol genes from $\mathrm{CcV}$ cluster within the totivirus and is most closely related to the $\mathrm{XdVgene}$ (Figure 7). It is to be noted is that all of these sequences are from terrestrial organisms and most from Fungi. It is, however, unclear if the sequences obtained from terrestrial plants are due to fungal infections or if they are using the plant cells as hosts (Roossinck 2010). Similarly, the CcV gag genes cluster with the XdV gene. However, the genomic gag gene did not cluster with the $\mathrm{CcV}$ sequences, but rather with the Saccharomyces and Scheffersomyces virus gene sequences. The gag gene it is sometimes reported to be of viral origin and sometimes to be of nuclear origin (Figure 7), but no clear phylogenetic pattern emerged.

Even though the nuclear gag gene was expressed and dsRNA coding for the gag and pol genes were present in C. crispus, inspections of TEM images showed no clearly 
identifiable virus-like particles (not shown) nor were any attempts to purify viral particles successful. Therefore, we are not presently convinced that viral particles are produced in $C$. crispus during normal conditions.

After finding the $\mathrm{CcV}$ in our gametophytic laboratory strain we wanted to know if this was specific for this strain and this life cycle stage. We therefore collected $C$. crispus from various locations and in different life cycle stages. The dsRNA could be visualized in all life stages tested, including tetrasporophytes and male and female gametophytes of C. crispus from Roscoff and in each part of the thallus tested. A band could also be seen in C. crispus samples from every location tested; in Europe from the northernmost location, Tjärnö in Sweden, via Plymouth in the UK, to the southernmost location, Porto in Portugal (Table 2). The band was also present with similar intensity in C. crispus with visible epiphytes and lesions. This indicates that the presence of dsRNA is wide-spread within $C$. crispus, at least along the European coast. For the laboratory strain with an origin in Canada, we cannot exclude an "infection" after the arrival of the strain in the laboratory in 1986.

We also wanted to verify if the presence of dsRNA was a phenomenon specific for C. crispus or if it was a more general occurrence. We therefore collected samples of other red algae around Roscoff, France (Table 3). A visible band was found in most of the red algae, except Palmaria palmata and Furcellaria lumbricalis, including one member of the Bangiales, a Porphyra/Pyropia species. This indicates that the presence of dsRNA identities of probable viral origin is wide-spread in red algae.

When the first sequence signatures showed similarities with totiviruses, which are mainly found in fungi or protozoa, we first suspected a contamination of C. crispus by epi- or endophytes in the culture medium. To exclude this, we decided to extract 
nucleic acids from protoplasts. In protoplasts, the cell wall is enzymatically digested with cellulase and carrageenase (Le Gall et al, 1990). The total nucleic acid extraction from protoplast was then obtained and a band of similar intensity was seen (Figure 7).

We consider $\mathrm{CcV}$ to be associated with $C$. crispus and not other eukaryotic organisms since it was found in extractions of RNA performed simultaneously with the DNA extractions for the genome project and no DNA from other eukaryotes were found during the genome analysis. The cultures of $C$. crispus are not axenic, so it is possible that the dsRNA virus is associated with bacteria. However, the virus was also present in extractions of RNA from protoplasts (Figure 7), where bacteria associated with the cell wall were drastically reduced. Totiviruses are also unknown from bacteria (Ghabrial and Suzuki 2009) and considering the amounts of dsRNA found on the gels we find it is highly likely that $\mathrm{CcV}$ is associated with C. crispus and not an associated organism. This is, at least, true for the Peggy's Cove strain. For the other samples microscopic analysis to localize endophytic fungi gave negative results (data not shown), but we cannot formally exclude that endophytic fungi associated with algae might be the host of totiviruses for these strains and species.

\section{CONCLUSIONS}

A totivirus-like entity closely related to viral strains that mostly infect fungal species exists in the red macroalga Chondrus crispus . Double-stranded viral RNA was found in relatively high quantities, but no viral particles were found, nor has any phenotype been identified. It is present in all tested life cycle stages and ubiquitous in C. crispus isolates from different geographic areas. In a limited sample very large 
sequence diversity was seen. Similar bands of dsRNA are present in other red algae.

To our knowledge, this is the first time a virus-related sequence has been reported from a red alga and the first time a totivirus is reported from algae. The $\mathrm{CcV}$ genome is organized as described in other totiviruses with two overlapping ORFs including a 5'-ORF coding a capsid protein (CP) and a 3'-ORF coding an RNA-dependent RNA polymerase. This involves an ORF disruption with an internal stop codon and a -1 ribosomal frameshift. A copy of the gene encoding the capsid was identified in the nuclear genome of $C$. crispus. Despite the fact that the presence of dsRNA seems to be widespread in red algae nothing is known about the physiological and ecological consequences of the association with totivirus-like entities.

\section{ACKNOWLEDGMENTS}

Work at the Station Biologique de Roscoff was supported by the Centre National de Recherche Scientifique, the University Pierre and Marie Curie, and IDEALG Grants ANR-10-BTBR-04-02 and 04-04 “Investissements d'avenir, BiotechnologiesBioressources". We also want to thank Marion Azidrou and Léa Cabioch for work performed early in the project, Anne-Claire Baudoux for expertise on viral particle precipitation, Gabriel Markov for CYP analysis, Simon Dittami for helpful comments, and Gunilla Toth and Isabel Sousa Pinto for collecting Chondrus crispus in Sweden and Portugal. 


\section{REFERENCES}

Allen, A., Islamovic, E., Kaur, J., Gold, S., Shah, D. \& Smith, T. J. 2011. Transgenic maize plants expressing the Totivirus antifungal protein, KP4, are highly resistant to corn smut. Plant Biotech. J. 9:857-64.

Apt, K. E. \& Gibor, A. 1991. The ultrastructure of galls on the red alga Gracilaria epihippisora. J. Phycol. 27:409-13.

Apt, K., Clendennen, S., Powers, D. \& Grossman, A. 1995. The gene family encoding the fucoxanthin chlorophyll proteins from the brown alga Macrocystis pyrifera. Mol. Gen. Genet. 246:455-64.

Baeza, M., Bravo, N., Sanhueza, M., Flores, O., Villarreal, P. \& Cifuentes, V. 2012. Molecular characterization of totiviruses in Xanthophyllomyces dendrorhous. Virol. J. 9:140.

Bekaert, M., Bidou, L., Denise, A., Duchateau-Nguyen, G., Forest, J. P., Froidevaux, C., Hatin, I., Rousset, J. P. \& Termier, M. (2003). Towards a computational model for- 1 eukaryotic frameshifting sites. Bioinformatics 19:327-35.

Bidou, L., Stahl, G., Grima, H., Liu, H., Cassan, M. \& Rousset, J. P. 1997. In vivo HIV -1 frameshifting efficiency is directly related to the stability of the stem-loop stimulatory signal. RNA 3:1153-8.

Brown, R. L., Kazan, K., McGrath, K. C., Maclean, D. J. \& Manners, J. M. 2003. A role for the GCC-box in jasmonate-mediated activation of the PDF1. 2 gene of Arabidopsis. Plant Physiol. 132:1020-32.

Bruenn, J. A. 1993. A closely related group of RNA-dependent RNA polymerases from double-stranded RNA viruses. Nucleic Acids Res. 21:5667-9. 
Brussaard, C. P., Noordeloos, A. A., Sandaa, R. -A. A., Heldal, M. \& Bratbak, G. 2004. Discovery of a dsRNA virus infecting the marine photosynthetic protist Micromonas pusilla. Virology 319:280-91.

Buttner, M. \& Singh, K. B. 1997. Arabidopsis thaliana ethylene-responsive element binding protein (AtEBP), an ethylene-inducible, GCC-box DNA binding protein interacts with an ocs element binding protein. Proc. Natl. Acad. Sci. USA 94:5961-6. Byun, Y. \& Han, K. 2009. PseudoViewer3: generating planar drawings of large-scale RNA structures with pseudoknots. Bioinformatics 25:1435-7.

Cao, S. \& Chen, S. J. 2006. Predicting RNA pseudoknot folding thermodynamics. Nucleic Acid Res. 34:2634-52.

Chen, C. \& Montelaro, R. C. 2003. Caracterization of RNA elements that regulate Gag-Pol ribosomal frameshift in equine infectious anemia virus. J. Virol. 77:102807.

Chen, S. J. \& Cao, S. 2009. Predicting structures and stabilities for H-type pseudoknots with interhelix loops. RNA 15:696-706.

Chiba, S., Kondo, H., Tani, A., Saisho, D., Sakamoto, W., Kanematsu, S. \& Suzuki, N. 2011. Widespread endogenization of genome sequences of non-retroviral RNA viruses into plant genomes. PLoS pathogens 7:e1002146.

Cock, J. M., Sterck, L., Rouzé, P., Scornet, D., Allen, A. E., Amoutzias, G., Anthouard, V. et al. 2010. The Ectocarpus genome and the independent evolution of multicellularity in the brown algae. Nature 465:617-21.

Collén, J., Cornish, M. L., Craigie, J., Ficko-Blean, E., Hervé, C., Krueger-Hadfield, S. A., Leblanc, C. et al. 2014. Chondrus crispus- a present and historical model organism for red seaweeds. Adv. Bot. Res. 71:53-90. 
Collén, J., Porcel, B., Carre, W., Ball, S. G., Chaparro, C., Tonon, T., Barbeyron, T. et al. 2013. Genome structure and metabolic features in the red seaweed Chondrus crispus shed light on evolution of the Archaeplastida. Proc. Natl. Acad. Sci. USA 110:5247-52.

Crochu, S., Cook, S., Attoui, H., Charrel, R. N., De Chesse, R., Belhouchet, M, Lemasson, J. J. et al. 2004. Sequences of flavivirus-related RNA viruses persist in DNA form integrated in the genome of Aedes spp. mosquitoes. J. Gen. Virol. 85:1971-80.

Cui, J. \& Holmes, E. C. 2012. Endogenous RNA viruses of plants in insect genomes. Virology 427:77-9.

Delaroque, N., Boland, W., Müller, D. G. \& Knippers, R. 2003. Comparisons of two large phaeoviral genomes and evolutionary implications. J. Mol. Evol. 57:613-2.

Delaroque, N., Müller, D. G., Bothe, G., Pohl, T., Knippers, R. \& Boland, W. 2001. The complete DNA sequence of the Ectocarpus siliculosus virus EsV-1 genome. Virology 287:112-32.

Derelle, E., Ferraz, C., Escande, M. L., Eychenié, S., Cooke, R., Piganeau, G., Desdevises, Y., Bellec, L., Moreau, H. \& Grimsley, N. 2008. Life-cycle and genome of OtV5, a large DNA virus of the pelagic marine unicellular green alga Ostreococcus tauri. PLoS One 3, e2250.

Derelle, E., Monier, A., Cooke, R., Worden, A. Z., Grimsley, N. H. \& Moreau, H. 2015. Diversity of viruses infecting the green microalga Ostreococcus lucimarinus. J. Virol. 89:5812-21.

Djikeng, A., Halpin, R., Kuzmickas, R., DePasse, J., Feldblum, J., Sengamalay, N., Afonso, C. et al. 2008. Viral genome sequencing by random priming methods. BMC Genomics 9:5. 
Etten, J., Lane, L. \& Meints, R. 1991. Viruses and virus like particles of eukaryotic algae. Microbiol. Rev. 55:586-620.

Friess-Klebl, A. K., Knippers, R. \& Müller, D.G. 1994. Isolation and characterization of a DNA virus infecting Feldmannia simplex (Phaeophyceae). J. Phycol. 30:653-8.

Fuhrman, J. A. 1999. Marine viruses and their biogeochemical and ecological effects. Nature 399:541-8.

Ghabrial, S. A. \& Nibert, M. L. 2009. Victorivirus, a new genus of fungal viruses in the family Totiviridae. Arch. Virol. 154:373-9.

Ghabrial, S. A. \& Suzuki, N. 2009. Virus of plant pathogenic fungi. Annu. Rev.

Phytopathol. 47:353-84.

Giedroc, D. P., Theimer, C. A. \& Nixon, P. L. 2000. Structure, stability and function of RNA pseudoknots involved in stimulating ribosomal frameshifting. J. Mol. Biol. 298:167-85.

Giuliano, G., Pichersky, E., Malik, V. S., Timko, M.P., Scolnik, P. A. \& Cashmore, A. R. 1988. An evolutionary conserved protein binding sequence upstream of a plant light-regulated gene. Proc. Natl. Acad. Sci. USA 85:7089-93.

Göker, M., Scheuner, C., Klenk, H. P., Stielow, J. B. \& Menzel, W. 2011.

Codivergence of mycoviruses with their hosts. PLoS One 6:e22252.

Holmes, E. C. 2011. The evolution of endogenous viral elements. Cell Host Microbe 10:368-77.

Ishihara, J., Pak, J. Y., Fukuhara, T. \& Nitta, T. 1992. Association of particles that contain double-stranded RNAs with algal chloroplasts and mitochondria. Planta $187: 475-82$

Ivey, R. G., Henry, E. C., Lee, A. M., Klepper, L., Krueger, S. K. \& Meints, R. H. (1996) A Feldmannia algal virus has two genome size-classes. Virology 220:267-73. 
Jacks, T., Madhani, H. D., Masiarz, F. R. \& Varmus, H. E. 1988. Signals for ribosomal frameshifting in the Rous sarcoma virus gag-pol region. Cell 55:447-58 Kapp, M., Knippers, R. \& Müller, D. G. 1997. New members of a group of DNA viruses infecting brown algae. Phycol. Res. 45:85-90.

Katzourakis, A. \& Gifford, R. J. 2010. Endogenous viral elements in animal genomes. PLoS Genet. 6:e1001191.

Klein, S. T. L. M., Ramsperger, U., Müller, D. G. \& Knippers, R. 1993. Genome structure of a virus infecting the marine brown alga Ectocarpus siliculosus. Virology 193:802-11.

Koga, R., Fukuhara, T. \& Nitta, T. 1998. Molecular characterization of a single mitochondria-associated double-stranded RNA in the green alga Bryopsis. Plant Mol. Biol. 36:717-24.

Koga, R., Horiuchi, H. \& Fukuhara, T. 2003. Double-stranded RNA replicons associated with chloroplasts of a green alga, Bryopsis cinicola. Plant Mol. Biol. 51:991-9.

Koonin E. V. 1991. Genome replication/expression strategies of positive-strand RNA viruses: a simple version of a combinatorial classification and prediction of new strategies. Virus Genes 5:273-81.

La Claire II, J. W. \& West, J. A. 1977. Virus-like particles in the brown alga Streblonema. Protoplasma 93:127-30.

Lang, A., Rise, M., Culley, A. \& Steward, G. 2009. RNA viruses in the sea. FEMS Microbiol. Rev. 33:295-323.

Le Gall, Y., Braud, J. P. \& Kloareg, B. 1990. Protoplasts production in Chondrus crispus gametophytes (Gigartinales, Rhodophyta). Plant Cell Rep. 8:582-5. 
557

558

559

560

561

562

563

564

565

566

567

568

569

570

571

572

573

574

575

576

577

578

579

580

Lee, R. E. 1971. Systemic viral material in the cells of the freshwater red alga

Sirodotia tenuissima (Holden) Skuja. J. Cell Sci. 8:623-31.

Liu, H., Fu, Y., Jiang, D., Li, G., Xie, J., Cheng, J., Peng, Y., Ghabrial, S. A. \& Yi,

X. 2010. Widespread horizontal gene transfer from double-stranded RNA viruses to eukaryotic nuclear genomes. J. Virol. 84:11876-87.

Liu, H., Fu, Y., Xie, J., Cheng, J., Ghabrial, S. A., Li, G., Peng, Y., Yi, X. \& Jiang, D. 2012. Evolutionary genomics of mycovirus-related ds RNA viruses reveals crossfamily horizontal gene transfer and evolution of diverse viral lineages. BMC Evol.

Biol. 12:91

Liu, H., Fu, Y., Xie, J., Cheng, J., Ghabrial, S. A., Li, G., Yi, X. \& Jiang, D. 2012.

Discovery of novel dsRNA viral sequences by in silico cloning and implications for viral diversity, host range and evolution. PloS one 7(7).

Magliani W., Conti S., Gerloni M., Bertolotti D. \& Polonelli L. 1997. Yeast killer systems. Clin. Microbiol. Rev. 10:369-400.

Maier, I., Wolf, S., Delaroque, N., Müller, D. G. \& Kawai, H. 1998. A DNA virus infecting the marine brown alga Pilayella littoralis (Ectocarpales, Phaeophyceae) in culture. Europ. J. Phycol. 33:213-20.

Minoia, S., Navarro, B., Covelli, L., Barone, M., García-Becedas, M. T., Ragozzino, A., Alioto, D., Flores, R. \& Di Serio, F. 2014. Viroid-like RNAs from cherry trees affected by leaf scorch disease: further data supporting their association with mycoviral double-stranded RNAs. Arch. Virol. 159:589-93.

Monier, A., Pagarete, A., de Vargas, C., Allen, M. J., Read, B., Claverie, J. -M. M. \& Ogata, H. 2009. Horizontal gene transfer of an entire metabolic pathway between a eukaryotic alga and its DNA virus. Genome Res. 19:1441-9. 
581

582

Moreau, H., Piganeau, G., Desdevises, Y., Cooke, R., Derelle, E. \& Grimsley, N. 2010. Marine prasinovirus genomes show low evolutionary divergence and acquisition of protein metabolism genes by horizontal gene transfer. J. Virol. $84: 12555-63$.

Müller, D. G. \& Frenzer, K. 1993. Virus infections in three marine brown algae:

Feldmannia irregularis, F. simplex, and Ectocarpus siliculosus. In Chapman, A. R.

O., Brown, M. T. \& Lahaye, M. [Eds.] Fourteenth International Seaweed

Symposium. Springer Netherlands, pp. 37-44.

Müller, D. G., Kawai, H., Stache, B. \& Lanka, S. 1990. A virus infection in the marine brown alga Ectocarpus siliculosus (Phaeophyceae). Bot. Acta 103:72-82.

Müller, D. G., Westermeier, R., Morales, J., Reina, G. G., Del Campo, E., Correa, J. A. \& Rometscha, E. 2000. Massive prevalence of viral DNA in Ectocarpus (Phaeophyceae, Ectocarpales) from two habitats in the North Atlantic and South Pacific. Bot. Mar. 43:157-9.

Oliveira, L. \& Bisalputra, T. 1978. A virus infection in the brown alga Sorocarpus uvaeformis (Lyngbye) Pringsheim (Phaeophyta, Ectocarpales). Ann. Bot. 42:439-45.

Pearson, M. N., Beever, R. E., Boine, B. \& Arthur, K. 2009. Mycoviruses of filamentous fungi and their relevance to plant pathology. Mol. Plant Pathol. 10:11528.

Philippe, N., Legendre, M., Doutre, G., Couté, Y., Poirot, O., Lescot, M., Arslan, D. et al. 2013. Pandoraviruses: Amoeba viruses with genomes up to $2.5 \mathrm{Mb}$ reaching that of parasitic eukaryotes. Science 341:281-6.

Pueschel, C. M. 1995. Rod-shaped virus-like particles in the endoplasmic reticulum of Audouinella saviana (Acrochaetiales, Rhodophyta). Can. J. Bot. 73:1974-80. 
Reinhold, H., Soyk, S., Šimková, K., Hostettler, C., Marafino, J., Mainiero, S., Vaughan, C. K., Monroe, J. D. \& Zeeman, S. C. 2011. $\beta$-Amylase-like proteins function as transcription factors in Arabidopsis, controlling shoot growth and development. Plant Cell 23:1391-1403.

Reisser, W. 1993. Viruses and virus-like particles of freshwater and marine eukaryotic algae — a review. Arch. Protistenkunde 143:257-65.

Ribas, J. C. \& Wickner, R. B. 1998. The Gag domain of the Gag-Pol fusion protein directs incorporation into the LA double-stranded RNA viral particles in Saccharomyces cerevisiae. J. Biol. Chem. 273:9306-11.

Roossinck, M. J. 2010. Lifestyles of plant viruses. Phil. Trans. R. Soc. B 365:18991905.

Routhier, E. \& Bruenn, J. A. 1998. Functions of conserved motifs in the RNAdependent RNA polymerase of a yeast double-stranded RNA virus. J. Virol. 72:4427-9.

Sambrook, J. \& Russell, D. W. 2006. Detection of DNA in agarose gels. CSH Protocols doi: 10.1101/pdb.prot4022.

Schenk, P. M., Elliott, A. R. \& Manners, J. M. 1998. Assessment of transient gene expression in plant tissues using the green fluorescent protein as a reference. Plant Mol. Biol. Rep. 16:313-22.

Schroeder, D. C. 2011. Viruses of seaweeds. In Hurst, J. C. [Ed.] Studies in viral ecology: Microbial and botanical host systems 1. John Wiley \& Sons, Inc., pp. 20515.

Seitz, S. B., Voytsekh, O., Mohan, K. M. \& Mittag, M. 2010. The role of an E-box element: multiple functions and interacting partners. Plant Signal. Behav. 5:1077-80. 
Seitz, S. B., Weisheit, W. \& Mittag, M. 2010. Multiple roles and interaction factors of an E-box element in Chlamydomonas reinhardtii. Plant Physiol. 152:2243-57. Sengco, M., Bräutigam, M., Kapp, M. \& Müller, D. 1996. Detection of virus DNA in Ectocarpus siliculosus and E. fasciculatus (Phaeophyceae) from various geographic areas. Europ. J. Phycol. 31:73-8.

Solano, R., Stepanova, A., Chao, Q. \& Ecker, J. R. 1998. Nuclear events in ethylene signaling: a transcriptional cascade mediated by ETHYLENE-INSENSITIVE3 and ETHYLENE-RESPONSE-FACTOR1. Genes Dev. 12: 3703-14.

Soyk, S., Šimková, K., Zürcher, E., Luginbühl, L., Brand, L. H., Vaughan, C. K., Wanke, D. \& Zeeman, S. C 2014. The enzyme-like domain of Arabidopsis nuclear $\beta$ amylases is critical for DNA sequence recognition and transcriptional activation. Plant Cell 26:1746-63.

Staiger, D., Kaulen, H. \& Schell, J. 1989. A CACGTG motif of the Antirrhinum majus chalcone synthase promoter is recognized by an evolutionary conserved nuclear protein. Proc. Natl. Acad. Sci. USA 86:6930-4.

Stevens, K., Weynberg, K., Bellas, C., Brown, S., Brownlee, C., Brown, M. T. \& Schroeder, D. C. 2014. A novel evolutionary strategy revealed in the phaeoviruses. PLoS ONE 9:e86040.

Suttle, C. A. 2005. Viruses in the sea, Nature 437:356-61.

Suttle, C. A. 2007. Marine viruses-major players in the global ecosystem. Nature Rev. Microbiol. 5:801-12.

Tournier, B., Sanchez-Ballesta, M. T., Jones, B., Pesquet, E., Regad, F., Latché, A., Pech, J. C. \& Bouzayen, M. 2003. New members of the tomato ERF family show specific expression pattern and diverse DNA-binding capacity to the GCC box element. FEBS letters 550:149-54. 
654 Tripodi, G. \& Beth, K. 1976. Unusual cell structures in tumor-like formations of

655 Gracilaria (Rhodophyta). Arch. Microbiol. 108:167-74.

656 Vignuzzi, M., Stone, J. K., Arnold, J. J., Cameron, C. E. \& Andino, R. 2006.

657 Quasispecies diversity determines pathogenesis through cooperative interactions in a

658 viral population. Nature 439:344-8.

659 West, J. A., Pueschel, C. M., Klochkova, T. A., Kim, G. H., de Goër, S. \&

660 Zuccarello, G. C. 2013. Gall structure and specificity in Bostrychia culture isolates

661 (Rhodomelaceae, Rhodophyta). Algae 28:83-92.

662 Williams, M. E., Foster, R. \& Chua, N. H. 1992. Sequences flanking the hexameric

663 G-box core CACGTG affect the specificity of protein binding. Plant Cell 4:485-96.

664 Zhai, Y., Attoui, H., Jaafar, F. M., Wang, H. Q., Cao, Y.X., Fan, S. P., Sun, Y. X. et

665 al. 2010. Isolation and full-length sequence analysis of Armigeres subalbatus

666 totivirus, the first totivirus isolate from mosquitoes representing a proposed novel

667 genus (Artivirus) of the family Totiviridae. J. Gen. Virol. 91:2836-45.

668 Zwart, M. P., Willemsen, A., Daròs, J. A. \& Elena, S. F. 2014. Experimental

669 evolution of pseudogenization and gene loss in a plant RNA virus. Mol. Biol. Evol.

$670 \quad 31: 121-34$.

671 
672 Table 1. Comparisons of \% identity between amino acid sequences obtained by 673 sequencing a dsRNA band from Chondrus crispus and comparing multiple 674 sequences for the pol gene. Sequences were translated to amino acids, aligned and 675 compared pairwise using Clustal Omega (www.ebi.ac.uk).

\begin{tabular}{lccccccc}
\hline & CcV1 & CcV2 & CcvP5 & CcvP6 & CcvP7 & CcvP8 & CcvP9 \\
\hline CcV1 & 100 & & & & & & \\
CcV2 & 37 & 100 & & & & & \\
CcvP5 & 44 & 52 & 100 & & & & \\
CcvP6 & 29 & 24 & 28 & 100 & & & \\
CcvP7 & 50 & 57 & 55 & 29 & 100 & & \\
CcvP8 & 23 & 21 & 26 & 19 & 26 & 100 & \\
CcvP9 & 50 & 61 & 52 & 32 & 65 & 27 & 100 \\
\hline
\end{tabular}

676 
677 Table 2. The presence of a detectable dsRNA band around $6 \mathrm{kbp}$ in RNA

678 extractions from Chondrus crispus.

\begin{tabular}{llll}
\hline Life cycle stage & Location & Virus \\
& & & detected \\
\hline Gametophyte male & Roscoff, France & $\left(48^{\circ} 43^{\prime} \mathrm{N}, 3^{\circ} 58^{\prime} \mathrm{W}\right)$ & Yes \\
Gametophyte female & Roscoff & Yes \\
Tetrasporophyte & Roscoff & Yes \\
Gametophytes & Roscoff & Yes \\
stressed* & & & \\
Gametophyte & Tjärnö, Sweden & $\left(58^{\circ} 86^{\prime} \mathrm{N}, 11^{\circ} 13^{\prime} \mathrm{E}\right)$ & Yes \\
Gametophyte & Plymouth, UK & $\left(50^{\circ} 39^{\prime} \mathrm{N}, 4^{\circ} 9^{\prime} \mathrm{W}\right)$ & Yes \\
Gametophyte & Helgoland, Germany & $\left(54^{\circ} 11^{\prime} \mathrm{N}, 7^{\circ} 53^{\prime} \mathrm{E}\right)$ & Yes \\
Gametophyte & Chaucre, France & $\left(45^{\circ} 59^{\prime} \mathrm{N}, 1^{\circ} 22^{\prime} \mathrm{W}\right)$ & Yes \\
Gametophyte & Lorient, France & $\left(47^{\circ} 42^{\prime} \mathrm{N}, 3^{\circ} 23^{\prime} \mathrm{W}\right)$ & Yes \\
Gametophyte & Viana do Castelo, & $\left(41^{\circ} 42^{\prime} \mathrm{N}, 8^{\circ} 51^{\prime} \mathrm{W}\right)$ & Yes \\
& Portugal & & \\
& & & \\
\hline
\end{tabular}

679

*Algae with visible epiphytes and lesions. 
681 Table 3. The presence of a detectable dsRNA band with a size around 6

$682 \mathrm{kbp}$ in different species of red macroalgae collected around Roscoff,

683 France.

\begin{tabular}{llc}
\hline Species & Class & Band detectable \\
\hline Dumontia contorta (S.G. Gmelin) Ruprecht & Florideophyceae & Yes \\
Grateloupia turuturu Yamada & Florideophyceae & Yes \\
Chondracanthus acicularis (Roth) Fredericq & Florideophyceae & Yes \\
Porphyra/Pyropia sp & Bangiophyceae & Yes \\
Laurencia pinnatifida (Hudson) J.V. & Florideophyceae & Yes \\
Lamouroux & & \\
Mastocarpus stellatus (Stackhouse) Guiry & Florideophyceae & Yes \\
Polysiphonia elongata (Hudson) Sprengel & Florideophyceae & Yes \\
Palmaria palmata (L.) Weber \& Mohr & Florideophyceae & No \\
Corallina elongata J. Ellis \& Solander & Florideophyceae & Yes \\
Furcellaria lumbricalis (Hudson) J.V. & Florideophyceae & No \\
Lamouroux & & \\
\hline
\end{tabular}


687

688

689

690

691

692

693

694

695

696

697

698

699

700

701

702

703

704

705

706

\section{FIGURE LEGENDS}

Figure 1. Agarose gel electrophoresis of nucleic acid extract from Chondrus crispus: A. native control (1), native control incubated $1 \mathrm{~h}$ at $40^{\circ} \mathrm{C}(2)$, DNAse1 treated (3), RNAse treated (4); L Smart Ladder (Eurogentec). B. Native control with $10 \%$ DMSO (1), after denaturing 5 min at $95^{\circ} \mathrm{C}$ with $10 \%$ DMSO.

Figure 2. Schematic representation of the Chondrus crispus viral sequences compared to the sequences of related viral sequences of Xanthophyllomyces dendrorhous (XdL1b, XdL2) and Saccharomyces cerevisiae (ScVL-A(L1)); note the presence of the viral capsid sequence integrated into the C. crispus genome ( $\mathrm{CcVGe}$ ). The capsid coding open reading frame (ORF) in blue, RNA dependent RNA polymerase coding ORF in red, and overlapping ORF in purple.

Figure 3. Alignment of domains in the RNA-dependent RNA polymerase ( $p o l$ ) gene from totiviruses as determined in Bruenn (2003) and Koonin (1991) with the Chondrus crispus dsRNA sequences. The consensus conserved domains described in Baeza et al. (2012) are highlighted.

Figure 4. Pseudoknot structure prediction of the CcV2 sequence using DotKnot method (based on Cao and Chen 2006, 2009) and drawn using PseudoViewer3 (Byun et al. 2009). 
708 Figure 5. Genome region of Chondrus crispus containing the gag gene homolog.

709 CYP: fragment of a cytochrome P-450 gene similar to a C. crispus nuclear gene (in 710 blue); E-Box, G-Box and GCC-Box (in grey boxes): cis-regulatory elements located 711 upstream the gag gene CcVGe (in red); open reading frame related to an unknown 712 protein found in Simkania nevegensis (in green); putative sigma-type promoters 713 (underlined in black); universal genetic code/yeast mitochondrial genetic code (in 714 italics).

716 Figure 6. A. An unrooted neighbor-joining tree of the capsid sequence (n, reported as 717 nuclear gene; v, reported as viral gene). B. An unrooted neighbor-joining tree of 718 RNA dependent RNA polymerase sequences. The alignment was based on entire sequences using Muscle and neighbor-joining analysis was carried out in MEGA.

721 Figure 7. Gel electrophoresis of nucleic acid extracts from C. crispus protoplasts on a $722 \quad 1 \%$ agarose gel stained with EtBr. L: smart Ladder Eurogentec 
Figure 1

A

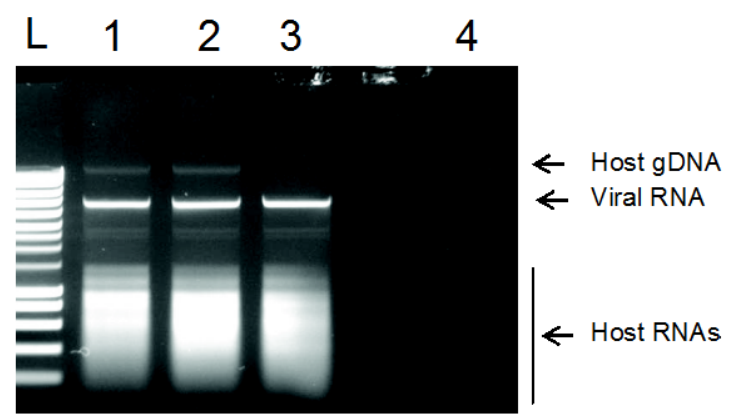

B

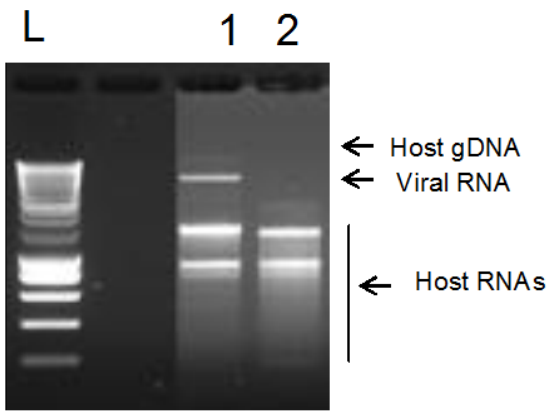


Figure 2

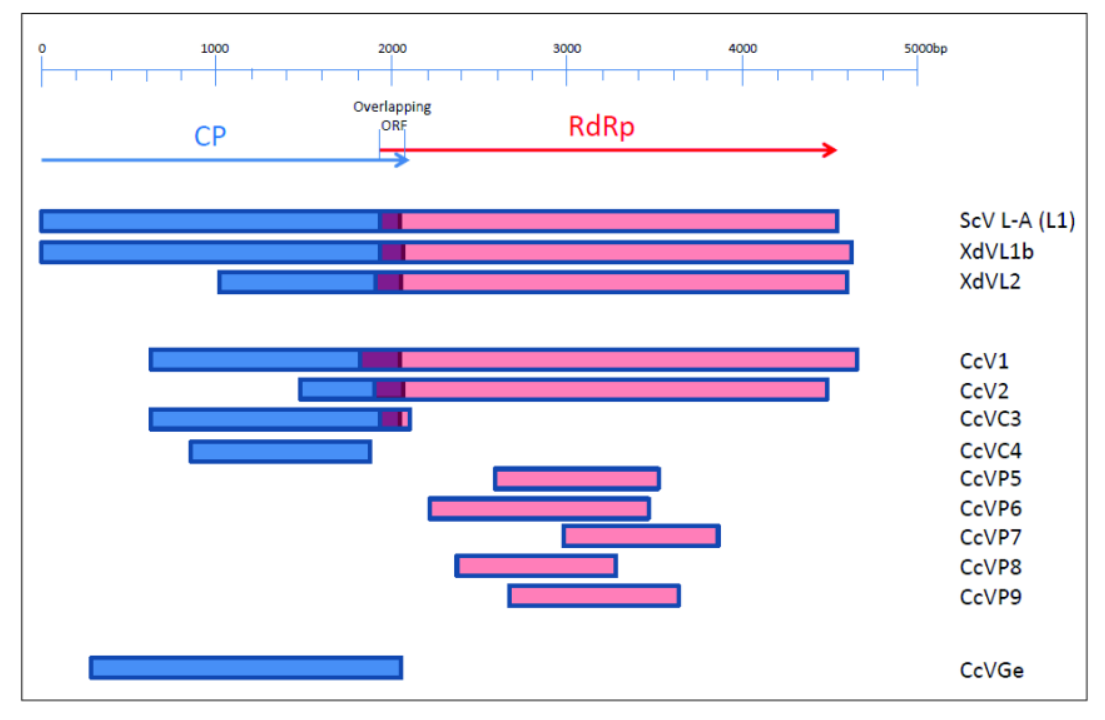




\begin{tabular}{|c|c|c|c|c|c|c|}
\hline \multirow[b]{2}{*}{$\begin{array}{l}\text { CcV1 } \\
\text { CcV2 } \\
\text { CVP9 } \\
\text { CcVP7 } \\
\text { CcVP5 } \\
\text { X. dendrorhous } \\
\text { X. dendrorhous } \\
\text { BI ack raspb erry } \\
\text { T. aestivum V1 } \\
\text { S. cer evisiae } \\
\text { CcVP8 } \\
\text { S. sego biensis } \\
\text { S. cerevisiae } \\
\text { CcVP6 }\end{array}$} & & \multicolumn{2}{|c|}{ 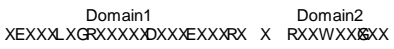 } & \multicolumn{3}{|c|}{$\begin{array}{l}\text { Domain3 } \\
\text { KXEXGKXXXI XXXDXXXYXXXXXXXXXXE}\end{array}$} \\
\hline & $\begin{array}{l} \\
\text { V-L1b } \\
\text { V-LL1a } \\
\text { Y F } \\
1 \\
\text { L-A } \\
\text { V-L Y } \\
\text { L-BC }\end{array}$ & 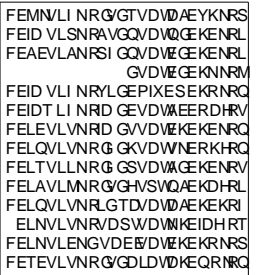 & 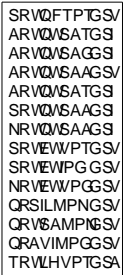 & \multicolumn{3}{|c|}{ 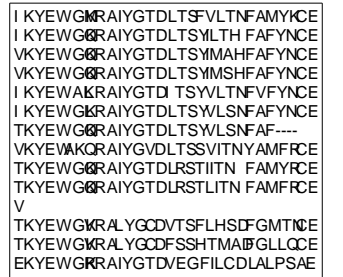 } \\
\hline & & $\begin{array}{cl}\stackrel{\text { Domain4 }}{\text { XDXXDFNSYHXX }} \times & \text { Domain5 } \\
\text { TLXSGXRXTT }\end{array}$ & & & & \\
\hline \multirow{3}{*}{$\begin{array}{l}\text { CcV1 } \\
\text { CcV2 } \\
\text { CcVP9 } \\
\text { CcVP7 } \\
\text { CcVP5 } \\
\text { X. dendrorhous } \\
\text { X. dendrorhous } \\
\text { Bl ack raspb erry } \\
\text { T. aestivum V1 } \\
\text { S. cerevisiae } \\
\text { CcVP8 } \\
\text { S. segobiensis } \\
\text { S. cerevisiae } \\
\text { CcVPF }\end{array}$} & & \multicolumn{2}{|c|}{ 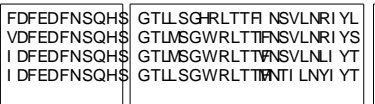 } & \begin{tabular}{|l|} 
I HNGDQL \\
VHNGXVM \\
VHNGDDM
\end{tabular} & \begin{tabular}{|l|} 
TKCYPFGMAFLRV \\
TKCSFGGLEFLRV
\end{tabular} & \begin{tabular}{|l} 
QYLTRAVATL \\
QMMTRNI ATL
\end{tabular} \\
\hline & $\begin{array}{l}\text { V- L1b } \\
\text { V- L1 a } \\
\begin{array}{l}\text { P } \\
1 \\
\text { L-A }\end{array}\end{array}$ & \multicolumn{2}{|c|}{ 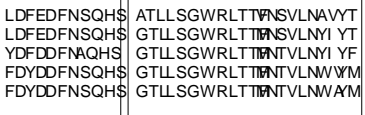 } & $\begin{array}{l}\text { LHNGDDN } \\
\text { LHNGDDN } \\
\text { VHNGDDN } \\
\text { VHNGDDM } \\
\text { VHNGDDM }\end{array}$ & $\begin{array}{l}\text { SKCAFGGIAEFLRI } \\
\text { SKCAVGAIAEFLI } \\
\text { AKGNVFSIGEFLRV } \\
\text { TKONVLSISEFLRI } \\
\text { AKGNLFSIS EFLRV }\end{array}$ & $\begin{array}{l}\text { QYLTRAI ATLM } \\
\text { QYLSRAVATMR } \\
\text { QYLSRAATLV } \\
\text { QYLSRSCATLV } \\
\text { QYLSRSCATLV }\end{array}$ \\
\hline & $\begin{array}{l}V-L \\
L-B C\end{array}$ & \multicolumn{2}{|c|}{\begin{tabular}{l|l} 
FDYDDFNSQH & GTLNSGWRLSFMTVLNRWL \\
YDFDDFNSQH & GTLSGWRLTTFNTALNYCYL
\end{tabular}} & $\mid \begin{array}{l}\text { LHNGDDF } \\
\text { LHNGDDF }\end{array}$ & $\begin{array}{l}\text { SKTNLGTIGEFLRV } \\
\text { TKMNIGTIAEFLRV }\end{array}$ & $\begin{array}{l}\text { QYLSRSVATLV } \\
\text { QYLTRGI ATFT }\end{array}$ \\
\hline
\end{tabular}




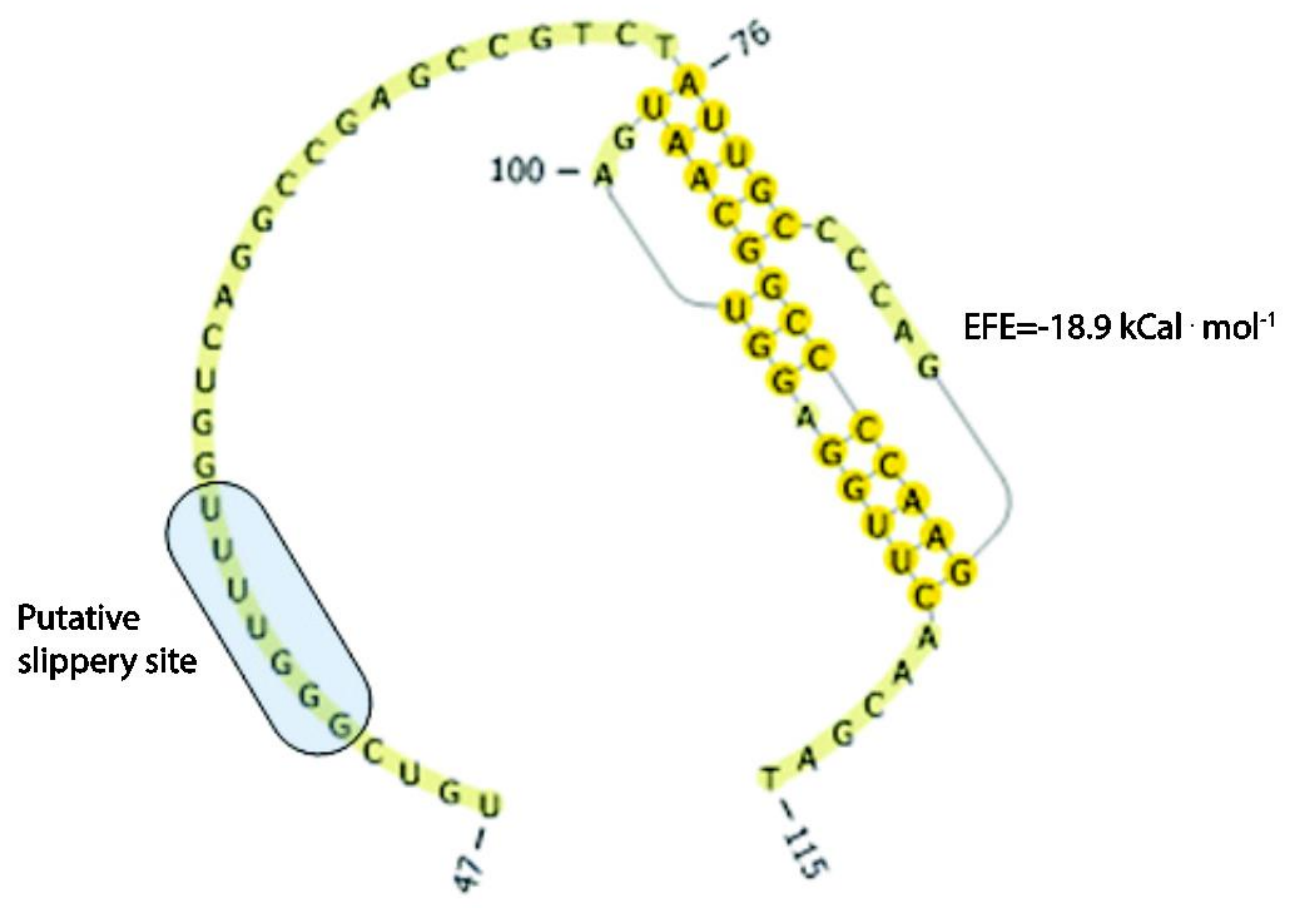


Figure 5

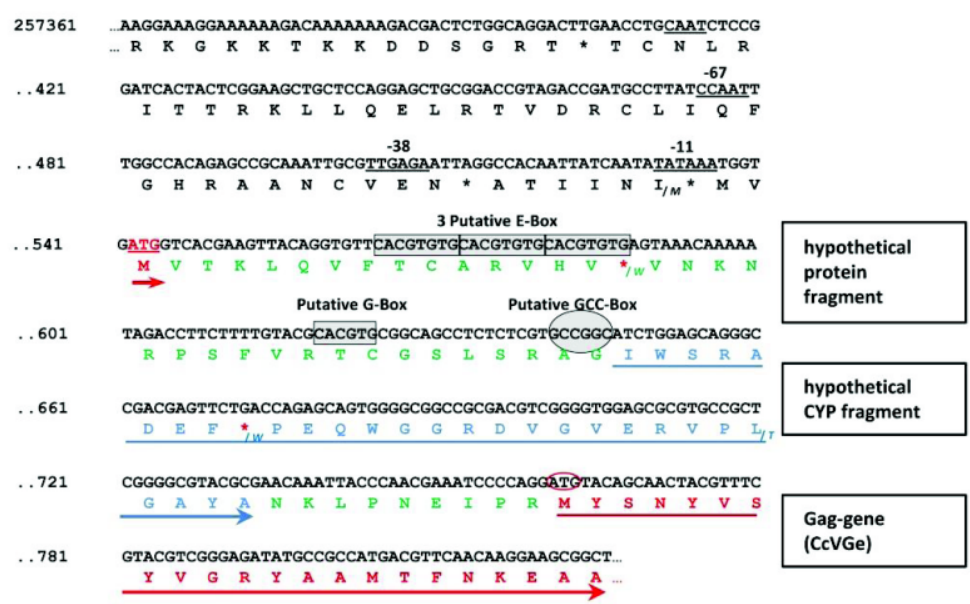


Figure 6
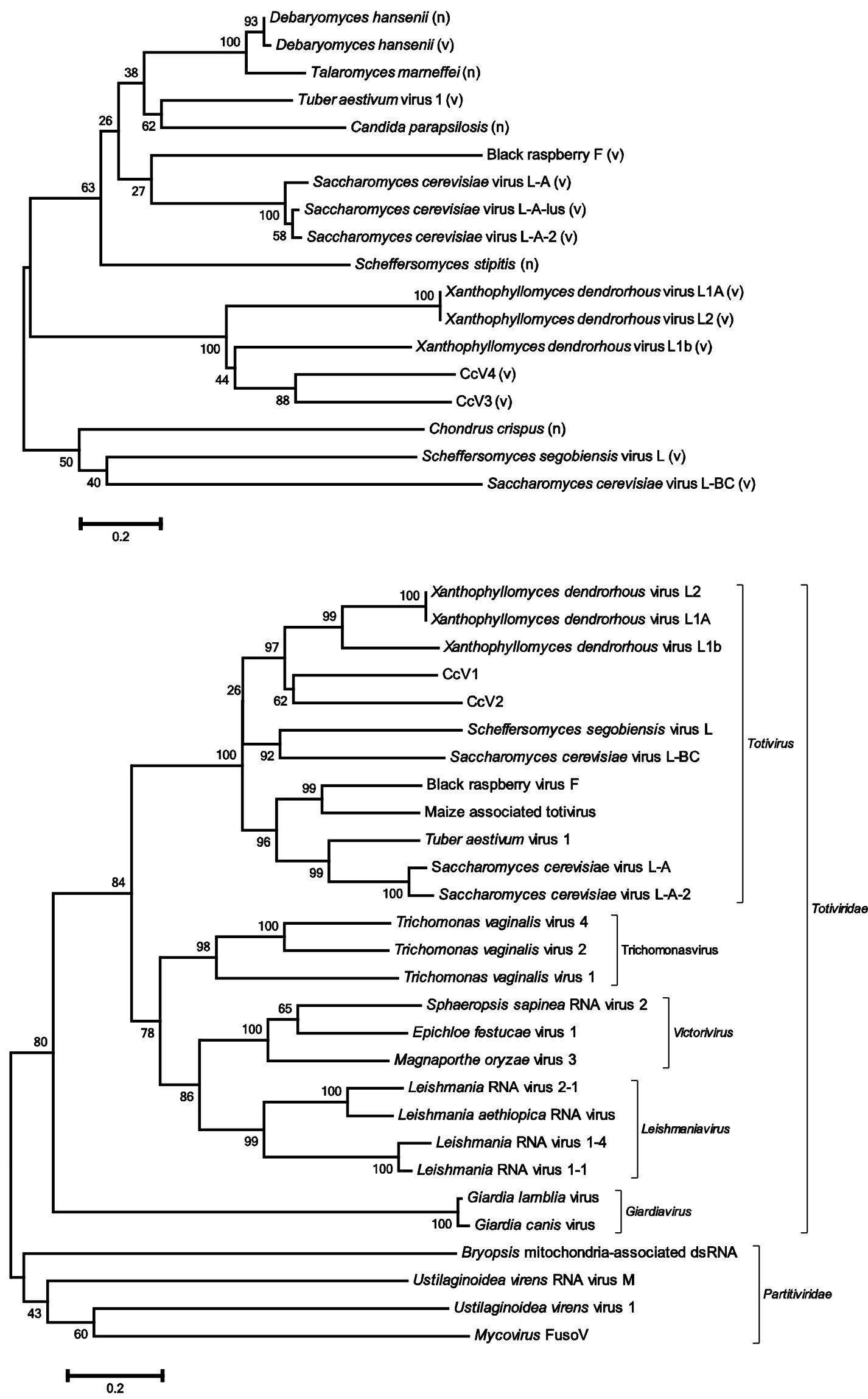
Figure 7

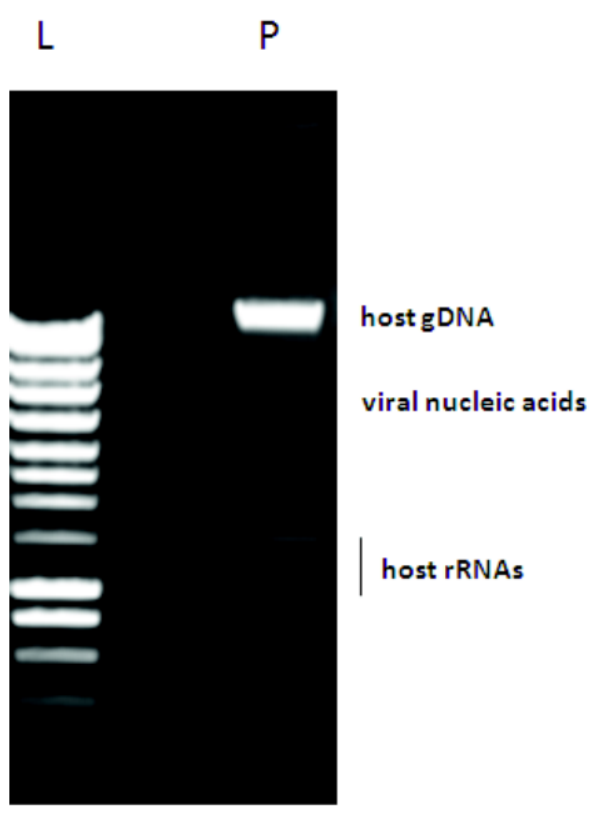

